\title{
ANALYSIS OF CONTRACT FARMING PATTERN AND INCOME COMPARISON OF POTATO FARMERS ON ATLANTIC AND GRANOLA VARIETIES
}

\author{
Dimas Brilian Syaban Pramana ${ }^{11}$ \& Mohammad Rondhi ${ }^{2}$ \\ ${ }^{1}$ Department of Agribusiness, Faculty of Agriculture, Jember University
}

\begin{abstract}
Contract farming is a practice in order to decrease the risk and uncertainty commonly done on farming. Generally, contract farming is divided into two types that are production contract and market contract. Contract farming is commonly done on the strategic and high-risk agricultural? commodities, one of them is the potato. Potato (Solanum tuberosum) is a commodity with high risk. One of the contract farming done on potato commodity is a contract occurred between farmer group and PT. "KLM" in Ijen District Bondowoso Regency, East Java Province Indonesia. The writer would like to review more related to the contract farming pattern occurred and compare the potato farmers' income following the contract farming and independent contract. This research was done from February until April 2019. Samples in this research used probability sampling on 106 potato farmers consisting of 76 farmers incorporated within contract farming and 29 farmers independently. The research results showed that contract farming intertwined was the contract farming type of market. The comparison of potato farmers income following the contract farming was lower than independent potato farmers income with the difference of IDR 4,515,417.49.
\end{abstract}

\footnotetext{
${ }^{1}$ Corresponding author: dimasbrilianspramana@gmail.com
} 


\section{INTRODUCTION}

The development of agriculture in this world recently has been arrived on a new stage. The new stage of the agriculture world recently is on the industrial era of 4.0. Agriculture on the industrial era of 4.0 of course until now is still experiencing some obstacles, especially in the developing countries. Those obstacles are caused by many farmers in the developing countries who have not been integrated with the technology entirely. One of the ways to transfer the technology to the farmers on this era by doing a contract farming. Contract farming literally can be defined as an agreement both oral and written between the farmers or framer group and manufacturing company or marketing as well as the corporation. The agreement in the contract agreed by related parties becomes a 'safety' form of farming activity done [1].

Contract farming is in truth a form transformation from the existing theory on the agricultural institution. Contract farming is the appropriate solution to transfer technology to the farmers which indirectly will have an implication on the economic acceleration of a country. Contract farming can integrate the component of farmer, marketer, and supplier directly. The integration of those three components can give a warranty from the aspect of quality and quantity when the product has truly arrived at the consumer [2,3]. Contract farming also can minimize the risk or the market failure and decrease the transaction cost which has an implication on the increase of the income earned by the farmers [4].

The risk and uncertainty on the farming commonly happened to have a long-term implication on the economy. The first risk source is uncertain input and output prices. Coordination and integration within contract farming will decrease the price risk until a certain limit. The second risk source is about the quality and quantity of an item that has to be fulfilled. It is almost impossible that the quantity within the open market is always fulfilled with the best quality entirely. The third risk source is the failure in the sustainability of the agricultural business. Sustainability is divided into two dimensions that are for human life and for the environment. On the traditional farming generally, the farmers are lack of understanding the sustainability [5]. The risk and uncertainty can be minimized through production contract and market contract [6,7].

[6] Stated that on the production contract, the company will participate in farming. The company will serve agricultural input, control asset, as well as decide the number and price of production result. Overall, the company gives a tight control of the farmer managerial aspect. Production contract experienced many failures in several countries. Those failures are commonly caused by the high labor cost to do a supervision [8]. On the implementation of autonomy market contract owned is more free and supple compared to the production contract. The market contract focuses on the magnitude of production and quality that will be produced from the farmers, as well as the delivery schedule that has been determined by company party [7].

The contract farming types of market and production contract have been done in the whole world especially in the developing countries in order to accelerate economic growth. Contract farming also participates in the modernization of developing country [8]. The research related to contract farming also has been done several agricultural commodities in developed as well as the developing country. Contract farming in America [6], Brazil [9], Sub-Saharan Africa [4], India [10], and Vietnam [11]. Based on the research that has been done, the contract farming in the implementation is different in each country and each commodity cultivated. The difference in contract farming is located on the technique of each commodity cultivated.

Contract farming will also experience a difference in the implementation no exception in the developing country such as Indonesia. On the developing country like Indonesia, contract farming is commonly done on the strategic commodities with very high risk. One of the commodities is potato. Potato commodity is a commodity which has high risk. It is remembered that until 2018 the consumption of potato in Indonesia is $2.56 \mathrm{~kg} / \mathrm{capita}$, not able to be fulfilled by national potato production $[12,13]$. Production fluctuation and price fluctuation on the potato commodity in Indonesia make this commodity risky enough to be cultivated independently. From the farmer side, potato farming is quite risky farming caused that it needs a quite high cost. The high cost in potato farming is caused by the seed cost [14]. Thus, it is necessary to do a cooperation one of them is by doing contract farming.

The researcher in this research would like to review more related to contract farming on potato farming. Different from the previous research that has been done by [10], on this research the researcher would like to review the contract farming on potato farming done by PT. "KLM" with a farmer group in Bondowoso Regency East Java Province Indonesia. The researcher will also compare the potato farming income between the farmers who follow the contract farming and the farmers who cultivate potato commodity with independent farming. This condition causes potato farmers to have a preference in joining contract farming. The aim of this research is to find out the contract farming on potato commodities it is truly beneficial for the farmers or the company. In addition,

\footnotetext{
${ }^{2}$ To maintain confidentiality in this research the name of a related company is changed into PT. KLM.
} 
researchers also want to find out what factors influence participation in contract farming potato comodities. 2.

\section{RESEARCH METHODS}

The research was done from February until April 2019 in Ijen District Bondowoso Regency East Java Province Indonesia. Bondowoso Regency is one of the strategic areas of agricultural development and buffer zone of regional food [15]. Bondowoso Regency is also one of six chosen regencies in East Java as national potato seed developer area [16]. The researcher is more specifically focusing on Ijen District because potato commodity is only cultivated at that place in Bondowoso Regency.

The sample retrieval method of this research used probability sampling. The technique used in this research was disproportionate stratified random sampling. Samples were obtained by the interview from 106 farmers consisting of 76 farmers incorporated within farmer group and 29 farmers who did independent farming. The research method used in this research was the descriptive and quantitative method. The descriptive data analysis method was used to explain the contract farming pattern covering the process of contract farming until the implementation. The implementation and the process of contract farming happening would be adjusted by the research that had been done by [6]. The quantitative data analysis method was done to compare the income earned by potato farmers who followed farmer group (planting Atlantic variety) and implemented the contract farming with potato farmers who cultivate independently (planting Granola variety). The researcher uses logistic regression to find out the factors that influence the participation of potato farmers in contracts farming.

\section{RESULT AND DISCUSSIONS}

Table 1. Roles of Each Party in Atlantic Potato Contract Farming

\begin{tabular}{ll}
\hline PT. KLM & Farmers \\
$\begin{array}{ll}\text { a. Serve quality potato seed of import Atlantic in the } & \text { a. Prepare land and other production facilities in accordance } \\
\text { form of loan } & \text { with the farmers' preference. }\end{array}$ \\
$\begin{array}{ll}\text { b. Buy potato result obtained by the farmers in } & \text { b. Be fully responsible for the plant and seed existing in the } \\
\text { field and be ready to implement the technical instruction } \\
\text { accordance with the quality determined. }\end{array}$ & $\begin{array}{ll}\text { and direction given by the company field officer. } \\
\text { c. Give technical guidance, workshop, and potato }\end{array}$ \\
$\begin{array}{ll}\text { c. Sell the yields of Atlantic potato only to the company (PT. } \\
\text { practical farming. }\end{array}$
\end{tabular}

\subsection{THE CONTRACT FARMING PATTERN OF POTATO FARMING}

The intertwined process of contract farming between PT. KLM and farmer group members in Ijen District Bondowoso Regency was started from the registration process On the case occurred the potato farmers did not directly intertwine a contract farming with the company Firstly, the potato farmers had to be incorporated first on a farmer group affiliated with PT. KLM. Farmer group has a role as a person in charge of potato farmers when incorporating into member until harvest. As long as the member farmer does not face an obstacle and produce a good product, the contact will keep continuing. On the scheme of contract farming occurred in Ijen District it does not have a certain deadline. Farmers are given freedom under the participation within the contract intertwined. Farmers can be not following to plant Atlantic variety in accordance with the contract intertwined. Although the farmer does not follow the contract, the farmer can keep following the contract farming as long as having a strong reason and a good track record.

Farmers who have been already incorporated to farmer group can implement the contract farming on potato farming which is done. The contract implementation is done by several stages that are the understanding related to the contract run, the determination of price and quota every planting season, and lastly, is contract implementation. Farmers understand the contract content not by understanding the contract content through writing, but through oral. The contract farming in the form of writing in writing along with the articles in detail is only known by the company party and the head of the farmer group. The following is the explanation related to contact farming content intertwined between the company and the farmers which have to be fulfilled by both sides.

Sources: Primary Data (2019)

Farmers who followed contract farming on potato farming only knew the practical technique shown in Table 1. At this condition, asymmetric information is possible to happen between the farmers and farmer group. However, contract farming intertwined gave quite tantalizing benefit for small farmers who had been just incorporated so that the farmers less criticize the condition. Contract farming run by the farmers in Ijen District also could increase farmers' standard of living one higher level before the existence of contract farming in Ijen District. Contract farming truly can increase farmers' income. The income earned is 
connected with the production cost and selling price from the commodity cultivated. On every early planting season, the company and farmer group will hold a routine meeting to give information related to selling price to company, purchase price of seed and quota of seed which can be given toward the company.

At the meeting, there are several limitations which can be reviewed deeper by the researcher. First, the company has a limitation to serve Atlantic potato seed because Atlantic potato seed with the best quality can be only fulfilled via import. The company does not fulfill all farmers' request because of the ability to manage production result. Thus, the company can manage the quota planted by the farmers. Second, the farmers have a limitation on unfavorable bargaining position from the existence of the contract. The bargaining position is related to price aspect, indeed on a certain condition, the price of potato on the contract farming is better than on the spot market. However, the farmers can do nothing because the practice so far is still prospering the farmers, and many cases are increasing the farmers' income [4,5]. This practice mostly happened in several countries around the world, commonly on commodities such as chili, tomato, cotton, and seedling [17]. Contract farming between the farmers and the company on Atlantic potato commodity can be categorized as a practical form of monopsony market $[4,17,18]$.

After the meeting process has been done to know the seedling cost, selling price of production, seedling quota, and other related technics, the farmers who follow the contract farming can start to process the land. The process of land processing overall until the harvest is not much different from the potato company of Granola variety (potato which is cultivated independently and marketed on the spot market). On the process of Atlantic potato farming, the company and the farmers have implemented each role. As far as this research is done, the obstacle from this contract farming is almost nothing. If there is an obstacle, that obstacle is still able to be communicated together with the group farmer as the mediator. On the whole, the main design from the scheme of implemented contract farming between the farmers and PT. KLM will be shown by the researcher in Table 2 as follows.

Table 2. The Implementation Scheme of Contract Farming of Potato Farming

\begin{tabular}{|c|c|}
\hline The Scheme of Contract Farming & The Implementation \\
\hline \multicolumn{2}{|l|}{ Output Control } \\
\hline Contract Characteristics & $\begin{array}{l}\text { The contract is communicated via oral together with the farmers incorporated } \\
\text { within the farmer group }\end{array}$ \\
\hline Selection Criteria of Farmers & No criteria of farmers \\
\hline Duration of Contract & Optional Corresponding to Farmers' Desire \\
\hline Quota Must be Supplied & The quota is not determined specifically \\
\hline $\begin{array}{l}\text { The Number of Farmers } \\
\text { Incorporated within the Contract }\end{array}$ & Unlimited, corresponding to the company's need \\
\hline Price Setting & Determined every early planting season \\
\hline Payment Procedure & Done a week after Atlantic potato has arrived at the factory \\
\hline \multicolumn{2}{|l|}{ Quality Standard } \\
\hline \multirow{2}{*}{\multicolumn{2}{|c|}{$\begin{array}{l}\text { Input Setting } \\
\text { Inecitication or Product Quality }\end{array}$}} \\
\hline & \\
\hline Technical Support & The company gives technical guidance but not completely participating \\
\hline \multicolumn{2}{|l|}{ Contract Enforcement } \\
\hline $\begin{array}{l}\text { The Procedure of } \\
\text { Resolution }\end{array}$ & Mediation between the farmers, farmer group, and company party \\
\hline Sanctions & Through legal channels \\
\hline
\end{tabular}

Sources: Primary Data (2019) 
Based on Table 2, it can be known that the contract farming on potato commodity that has been implemented in Ijen District and reviewed by the research done by [6] is contract farming form of market type. This research showed that the result in line with the research done by $[6,8]$. The contract farming type of dominant market moves to food subsector, on some cases there is horticulture subsector and the seedling, different from the contract farming type of production that is in the majority dominant at livestock subsector.
The income is one of the important components which become the farmers' motive to follow the contract farming. On the field condition, the potato farmers in Ijen District do not follow the contract farming entirely so that the income earned by the contract farming and independent farmers will be different. In this research, the average land area of Atlantic potato farming is 1.17 hectare, while the average land area of Granola potato farming is 0.54 hectare. The following is shown in Table 3 to know more clearly about the component of costs on Atlantic and Granola potato farming.

\subsection{Income Comparison of Atlantic and Granola Potato Farming in Ijen District}

Table 3. The Average Production Cost of Atlantic and Granola Potato Farming in One Hectare

\begin{tabular}{|c|c|c|c|c|c|c|}
\hline \multirow[t]{2}{*}{ No. } & \multirow[t]{2}{*}{ Explanation } & \multirow{2}{*}{ Unit } & \multicolumn{2}{|c|}{ Value } & \multicolumn{2}{|c|}{ Percentage } \\
\hline & & & Contract Farming & Independent & Contract Farming & Independent \\
\hline \multicolumn{7}{|c|}{ Variable Cost } \\
\hline 1 & Seedling Cost & IDR/ha & $30,581,717$ & $46,833,863$ & $47.7 \%$ & $60.7 \%$ \\
\hline 2 & Fertilizer Cost & IDR/ha & $3,580,316$ & $3,400,413$ & $5.6 \%$ & $4.4 \%$ \\
\hline 3 & Drug Cost & IDR/ha & $10,060,717$ & 10.444 .632 & $15.7 \%$ & $13.5 \%$ \\
\hline 4 & Labor Cost & IDR/ha & $7,911,247$ & 9.937 .294 & $12.3 \%$ & $12.9 \%$ \\
\hline 5 & Net Cost & IDR/ha & 660,410 & 793.482 & $1.0 \%$ & $1.0 \%$ \\
\hline 6 & Transportation Cost & IDR/ha & $7,656,011$ & 1.829 .098 & $11.9 \%$ & $2.4 \%$ \\
\hline 7 & Fuel Cost & IDR/ha & 99,466 & 99.705 & $0.2 \%$ & $0.1 \%$ \\
\hline 8 & Land Lease Cost & IDR/ha & $3,200,000$ & 3.200 .000 & $5.0 \%$ & $4.1 \%$ \\
\hline Tota & Variable Cost & & $63,749,884$ & 76.538 .486 & $99.5 \%$ & $99.2 \%$ \\
\hline \multicolumn{3}{|c|}{ Fixed Cost } & & - & - & \\
\hline 1 & Depreciation of Equipment & IDR/ha & 332,908 & 622.478 & $0.5 \%$ & $0.8 \%$ \\
\hline \multicolumn{2}{|c|}{ Total Fixed Cost } & IDR/ha & 332,908 & 622.478 & & \\
\hline Total & Farming Cost & IDR/ha & $64,082,793$ & 77.160 .964 & $100 \%$ & $100 \%$ \\
\hline
\end{tabular}

Sources: Primary Data (2019)Based on Table 3 the highest production cost on potato farming of Atlantic and Granola varieties is seedling cost. The seedling cost has proportion respectively $47.7 \%$ of the total cost of Atlantic variety, and $60.7 \%$ of the total cost of Granola variety. The seedling cost of Atlantic potato is lower than Granola potato that this thing is caused by the availability of Granola potato seedling which is unlimited in number so that it is suitable with the economic law applied that the price of Granola potato seedling will be higher. On the activity of Atlantic and Granola potato farming, the fertilizer used is not far different. The combination of the fertilizer among others urea fertilizer, phonska fertilizer, Za fertilizer, and SP 36 fertilizer. Drug cost on potato farming on the farmers who apply Granola variety tends to be higher of IDR 383.915, this is caused by several respondents of independent farmers have the desire to follow the contract farming. That condition makes respondent farmers adopt a farming way to be applied the contract farming, however, on the implementation, there is no more technical guidance obtained remembering that independent potato farming is not guided by the expert officer. Potato farming done by independent farmers without suitable technical guidance will increase the failure risk on the farming that is done. Other risks may occur are on the sustainability aspect and environment. That condition is in accordance with the statement [5].
The labor cost on the farming of Atlantic and Granola potato varieties in Ijen District Bondowoso Regency respectively has a proportion of $12 \%$. The highest labor cost is spent by the farmers when the planting and the harvest. Related to the net cost of granola farming which is higher caused by the farmer group give the lower price of the net to their members. Transportation cost of the farmers who cultivate Atlantic variety tends to be higher of IDR 5,826,913 that is because the Atlantic potato has to be sent to the manufacturing company of PT. KLM located in Central Java. The equipment used to potato farming of Atlantic and Granola varieties in Ijen District among others hoe, sickle, bucket, diesel engine, drum, hose, and tarpaulin. Related to production result and the income of potato farming of Atlantic and Granola varieties will be shown in Table 4 as follows. 
Table 4. The Comparison of Atlantic and Granola Potato Farming in One Hectare in Ijen District Bondowoso Regency

\begin{tabular}{|c|c|c|c|c|c|c|}
\hline Variable & B & S.E. & Wald & $\mathrm{df}$ & Sig. & $\begin{array}{l}\operatorname{Exp}( \\
\text { B) }\end{array}$ \\
\hline Age $\left(\mathrm{X}_{1}\right)$ & -.104 & .054 & 3.764 & 1 & $.052 *$ & .901 \\
\hline $\begin{array}{l}\text { Number of } \\
\text { Family } \\
\text { Members }\left(X_{3}\right)\end{array}$ & 2.661 & .994 & 7.172 & 1 & $.007 * *$ & 14.308 \\
\hline $\begin{array}{l}\text { Farming } \\
\text { Experience }\left(\mathrm{X}_{4}\right)\end{array}$ & -.119 & .066 & 3.273 & 1 & $.070^{*}$ & .888 \\
\hline Land Area $\left(\mathrm{X}_{5}\right)$ & 1.860 & 1.090 & 2.912 & 1 & $.088 *$ & 6.421 \\
\hline $\begin{array}{l}\text { Risk Prefrence } \\
\left(\mathrm{X}_{7}\right)\end{array}$ & 1.607 & .774 & 4.309 & 1 & $.038^{* *}$ & 4.989 \\
\hline $\begin{array}{l}\text { Risk Averse } \\
\left(\mathrm{X}_{8}\right)\end{array}$ & -1.727 & .832 & 4.309 & 1 & $.038 * *$ & .178 \\
\hline $\begin{array}{l}\text { Livestock } \\
\text { Ownership }\left(D_{1}\right)\end{array}$ & -4.517 & 1.585 & 8.124 & 1 & $.004 * *$ & .011 \\
\hline Constant & -4.772 & 5.243 & .828 & 1 & .363 & .008 \\
\hline \multirow{2}{*}{ Explanation } & \multirow{2}{*}{ Unit } & \multicolumn{5}{|c|}{ Value } \\
\hline & & Contra & ct Farm & & \multicolumn{2}{|c|}{ Independent } \\
\hline $\begin{array}{l}\text { Results of } \\
\text { Potato } \\
\text { Production }\end{array}$ & $\mathrm{Kg} / \mathrm{Ha}$ & \multicolumn{3}{|c|}{$13,985.48$} & \multirow{2}{*}{\multicolumn{2}{|c|}{8,079}} \\
\hline $\begin{array}{l}\text { Price of } \\
\text { Potato }\end{array}$ & $\mathrm{IDR} / \mathrm{Kg}$ & \multicolumn{3}{|c|}{7,720} & & \\
\hline Reception & \multirow{2}{*}{$\begin{array}{l}\text { IDR/Ha } \\
\text { IDR/Ha }\end{array}$} & \multicolumn{3}{|c|}{$107,967,942.38$} & \multicolumn{2}{|c|}{$125,561,531.13$} \\
\hline $\begin{array}{l}\text { Farming } \\
\text { Cost }\end{array}$ & & \multicolumn{3}{|c|}{$64,082,793.61$} & \multicolumn{2}{|c|}{$77,160,964.87$} \\
\hline Income & IDR/Ha & \multicolumn{3}{|c|}{$43,885,148.77$} & \multicolumn{2}{|c|}{$48,400,566.26$} \\
\hline
\end{tabular}

Sources: Primary Data (2019)

Based on table 4 the production result of Granola potato is higher on the same land area because the size of the Granola potato is bigger than the Atlantic one. The price of Granola potato on this research recently is done higher than Atlantic potato with the difference of price of IDR 359. The reception, farming cost, and the income of Granola potato farming are higher than Atlantic potato. The difference in income of Granola and Atlantic potatoes is IDR 4,515,417.49. The income of Granola potato farming is higher in certain moments, however, the higher income will always be accompanied by the high risk. The contract farming done is a form of risk distribution on potato farming, that is balanced with the effect of constant income received by the farmers [19].

\subsection{Factors That Influence Potato Farmers' Decision to Conduct Partnerships}

In this study several factors were selected that influenced the farmers' decision to partner with potato farming in Ijen Subdistrict. These factors include age (X1), education (X2), number of family members (X3), farming experience (X4), land area (X5), income (X6), risk preference $(\mathrm{X} 7)$, risk aversion level (X8), and livestock ownership (X9). This research uses the stepwise (backward wald) method, a partial significance test is carried out to get the variables that really fit the model. According to [20] the stepwise (backward and forward) method is by far one of the most useful predictors that can be used in equations in the test of the significance of a model. The backward method is one of the most frequently used methods because in that method all the variable equations have nothing left behind and produce variables that are completely aligned with the model used by the researcher. The backward method in principle has the same concept as the enter method, it's just that the method starts by entering all variables into the regression model. Then at each stage the incoming variables will be evaluated, meaning that these variables can leave the model. Variables that leave the model generally will have a significance value of more than $(0.1)$. In general, the test criteria that must be met in this method are the same as the enter method. Following are the results of the logistic regression analysis that will be presented in table 5 .

Table 5. Results of Logistic Regression Analysis

\begin{tabular}{lll}
\hline Output & Sig. & Value \\
\hline $\begin{array}{l}\text { Omnibus Test of Model } \\
\text { Coefficient }\end{array}$ & 0,000 & 96,850 \\
Nagelkerke R Square & 0,000 & 0,867 \\
-2 Log Likelihood (step 0) & 0,977 & 124,400 \\
-2 Log Likelihood (step 1) & 0,000 & 27,549 \\
Classification Table & 0,000 & $97,2 \%$ \\
Hosmer and Lemeshow's & 0,078 & 14,134 \\
\end{tabular}

Sources: Primary Data (2019)

In this study using the Wald Test to determine the significance of each variable independently of the dependent variable. The following is the Wald Test output presented in table 6 .

able 6. Output Variable in the Equation in the Logistics Model Regarding Decision Making of Potato Farmers Conducting Partnerships

Sources: Primary Data (2019)

From the results of the output variable in the equation in the logistical model regarding the decision making of potato farmers in partnership, the following equation is obtained:
$\mathrm{Yi}=\frac{\mathrm{e}^{-4.77-0.10 \mathrm{X}_{1}+2.66 \mathrm{X}_{3}-0.11 \mathrm{X}_{4}+1.86 \mathrm{X}_{5}+1.60 \mathrm{X}_{7}-1.72 \mathrm{X}_{8}-4.51 \mathrm{D}_{1}}}{1+\mathrm{e}^{-4.77-0.10 \mathrm{X}_{1}+2.66 \mathrm{X}_{3}-0.11 \mathrm{X}_{4}+1.86 \mathrm{X}_{5}+1.60 \mathrm{X}_{7}-1.72 \mathrm{X}_{8}-4.51 \mathrm{D}_{1}}}$

The following is an explanation of the logistic regression model regarding the effect of independent variables on potato farmers' decision making in conducting contract farming:

1. Age (X1)

Based on the results of logistic regression analysis the age variable has a significance value of 0.052 . The age variable significantly affects the decision making of potato farmers in contract farming. The coefficient value $(B)$ on the age variable of -0.104 means that the 
probability of the respondent farmers' age variable in participating in contract farming is lower than not joining contract farming. This condition cause younger farmers have an open mind on innovations or renewable matters. Different things for older farmers, farmers tend to be difficult and reluctant to accept the latest trends or innovations such as the implementation of contract farming. Older farmers also tend to be unable to meet targets if there is a contract farming. This is because the age of potato farmers greatly affects productivity. The statement also agrees with [21].

\section{Education (X2)}

Based on the results of the logistic regression analysis that Education has done is one of the variables released through the analysis process. Educational variables are excluded because these variables are not significant or have a significance value of more than (0.1). Based on the conditions in the field, the factor of the length of formal education received by farmers in potato farming activities does not significantly affect the participation in contract farming. The participation of farmers in contract farming is more influenced by non-formal education that obtained by farmers. Nonformal education makes people interested in joining a contract farming, especially education provided by company field officers. Research conducted by researchers was in line with previous studies. Based on research conducted previously by [22-25], educational variables are not significant variables in decision making partnered. Research conducted by [24] states that education variables cause bias in the significance test because the probability of the coefficients found is in average education. Similar results were found in a study conducted by [25] in that study educational variables came out of the equation model.

3. Number of family members (X3)

Based on the results of the logistic regression analysis variable the number of family members obtained a significance value of 0.007 . The variable number of family members significantly affected the decision making of potato farmers in conducting contract farming. Coefficient value (B) variable number of family members is 2,661. Based on the results of the logistic regression analysis it is stated that the number of members positively influences the decision making of potato farmers in conducting contract farming. This tendency is motivated by economic motives, where the more family members, the more expenses will be spent. The more expenses will affect the economic burden in a family. This resulted in farmers as family heads looking for alternatives to meet family needs, one of which was by joining a contract farming in potato farming.

4. Farming Experience (X4)
Based on the results of logistic regression analysis the farm experience variable has a significance value of 0.070. The farming experience variable significantly influences the decision making of potato farmers in conducting contract farming. The coefficient value (B) on the farm experience variable is -0.119 . The results of this study are in line with previous studies conducted by [25-28]. In the previous research, it was stated that farming experience was one of the variables that influenced farmers' participation in contract farmings. Farmers who have relatively young farming experience tend to partner to reduce the risk of failure. Some farmers with high farming experience also have relationships with potato seed providers so they can get cheaper prices and higher quality potato seeds. This makes farmers with higher farming experience have a tendency to not participate in contract farming.

\section{Land Area (X5)}

Based on the results of the logistic regression analysis of land area variables, a significance value of 0.088 is obtained. Land area variable significantly influences the decision making of potato farmers in conducting contract farming. The coefficient value (B) of the land area variable is 1.86 . The land area variable is one of the variables that influence the contract farming, which is in line with research conducted by $[23,26,27,29,30]$. The research is in accordance with the conditions in the field where farmers with large areas of land have a perspective of failure of potato farming will cause huge losses when working on large areas of land. To minimize this, farmers with large areas of land tend to reduce the risks involved by partnering. The opposite happened with potato farmers with small land area.

6. Revenue (X6)

Based on the results of linear regression analysis using the backward wald method, the results obtained are seven variables that pass the test while the remaining two variables do not pass the test. One of the variables that did not pass the test was income variable because this variable had a significance value of more than (0.1). Based on the field conditions, potato farmers in Ijen Subdistrict are more involved in the contract farming due to capital loans from the contract farming itself and price certainty. The capital loan referred to here is a potato seed loan that can cut the cost of potato farming. Income in potato farming is also insignificant because potato farmers not only work on potato commodities but also simultaneously work on other commodities namely cabbage. Revenue is influenced by several other factors such as the amount of input costs, production quantities, and selling prices. In the field conditions, farmers who did not implement the contract farming due to the limited supply of 
seedlings provided by the company, generally applied the potato farming pattern almost the same as the farmers who implemented the contract farming. These conditions cause farming costs incurred by potato farmers who do not implement contract farming can be higher due to lack of technical guidance. Several previous studies conducted by [22,31] stated that the income variable in farming does not affect the participation of farmers in contract farming. Based on research conducted by [31] it was stated that indeed very little research related to the effect of income on participation in contract farmings, and none of the studies could explain the relationship of income to the context of risk.

\section{Risk Aversion Level (X8)}

Based on the results of logistic regression analysis the risk aversion level variable has a significance value of 0.038. Variable has a significant effect on the decision making of potato farmers in conducting contract farmings. Risk aversion level factors influence the participation of potato farmers in contract farmings. The coefficient value (B) on the risk aversion level variable of -1.727. Risk aversion level is proven to be one of the variables that influence the participation of potato farmers in contract farmings that have a negative influence. Based on the findings in the field of risk aversion, the majority of potato farmers are on a scale of one. The majority of potato farmers want to work on potato farming with all the land leased to join the contract farming, but the availability of seedlings provided by the company cannot meet the farmers' demand. Participation in the contract farming hopes that there is no price risk that occurs again in potato farmers so that potato farmers get maximum income.

9. Livestock Ownership (X9)

Based on the results of logistic regression analysis of livestock ownership variables having a significance value of 0.004 , it variables significantly influence the decision making of potato farmers in making contract farmings. Livestock ownership factors influence the participation of potato farmers in contract farmings. The coefficient value (B) on the livestock ownership variable of $-4,517$. Livestock ownership is the most influential variable in farmers' participation in the contract farming of potato farming. The results of this study are in line with research conducted by [1]. Generally livestock ownership has a role as assets, capital reserves, or savings in meeting daily needs in farming communities which indirectly influences decision making in contract farming participation $[24,25]$. Potato farmers who are not partnering have a majority of ruminants. Potato farmers who still have assets (livestock) tend not to partner because their perceptions regarding the capital owned can still be sufficient for the business carried out and the necessities of daily life.

\section{CONCLUSIONS}

The contract farming pattern applied between potato farmers of Atlantic variety and PT. KLM in Ijen District Bondowoso Regency is a contract farming pattern of market type. On the contract farming pattern of market type, the company does not participate entirely in the farming activity. On the contract farming of market type, the company will serve the certainty of the price the market on the farmers who cultivate. Related to the implementation and contract process did there is no obstacle. The income of potato farmers cultivating Atlantic potato is lower than independent potato farmers with the difference of IDR $4,515,417.49$. The research done by the researcher can be developed by discussing deeper related to asymmetric information. Factors that influence the decision making of potato farmers in conducting contract farmings are significant namely the age variable has a negative relationship, the variable number of family members has a positive relationship, the farm experience variable has a positive relationship, the land area variable has a positive relationship, the risk preference variable has a positive relationship, The risk aversion level variable has a negative relationship, and the livestock ownership variable has a negative relationship, while the education variable and income variable are not significant to the decision making of potato farmers to make a contract farming.

\section{REFERENCES}

1. V. Miglani, S. Kalamkar, and D. Shah, in 30Th Int. Conf. Agric. Econ. (2018), pp. 1-28

2. J. Harwood, R. Heifner, K. Coble, J. Perry, and A. Somwaru, Managing Risk in Farming: Concepts, Research and Analysis (US Department of Agriculture, Washington, 1999)

3. C. Eaton and A. W. Shepherd, Contract Farming - Partnerships for Growth (FAO, Roma, 2001)

4. C. Oya, J. Agrar. Chang. 12, 1 (2012)

5. E. Rehber, Contract Farming in Practice: An Overview (Connecticut, 2019)

6. J. M. MacDonald and P. Korb, Ssrn (2012)

7. F. Rustiani, H. Sjaifudian, and R. Gunawan, Mengenal Usaha Pertanian Kontrak (Contract Farming) (AKATIGA, Bandung, 1997)

8. K. Otsuka, Y. Nakano, and K. Takahashi, Ssrn 1 (2016)

9. K. Watanabe, N. S. Paiva, A. E. Bressan, and S. Lourenzani, Rev. Direito GV 13, 95 (2017)

10. A. Dutta, A. Dutta, and S. Sengupta, IOSR J. Bus. Manag. 75 (2016)

11. C. Saenger, M. Qaim, M. Torero, and A. Viceisza, Agric. Econ. (United Kingdom) 44, 297 (2013)

12. B. P. Statistika, Statistik Tanaman Sayuran Dan 
Buah-buahan Semusim Indonesia 2017 (Badan Pusat Statiistik, Jakarta, 2018)

13. K. Pertanian, Statistik Konsumsi Pangan Tahun 2018 (Kementrian Pertanian, Jakarta, 2018)

14. N. Oktaviana, S. M. Handayani, and S. W. Ani, Univ. Sebel. Maret (2013)

15. Kasutjianingati, L. D. Soelaksini, S. Rahayu, and Prayitno, J. Pengabdi. Masy. J-DINAMIKA 1, 116 (2016)

16. B. Sayaka, S. M. Pasaribu, and J. Hestina, Anal. Kebijak. Pertan. 10, 31 (2012)

17. S. SIVRAMKRISHNA And A. JYOTISHI, J. Int. Dev. 20, 280 (2008)

18. D. Glover and K. Kusterer, Small Farmers, Big Business: Contract Farming and Rural Development . David Glover, Ken Kusterer (The Macmillan Press LTD, London, 1990)

19. C. R. Knoeber and W. N. Thurman, Am. J. Agric. Econ. 77, 486 (1995)

20. N. R. Drapper and H. Smith, Applied Regression Analysis, Third (John Wiley \& Sons, New York, 1998)

21. S. Kumar, P. Chand, J. P. S. Dabas, and H. Singh, Indian J. Agric. Econ. 65, 621 (2010)

22. A. Pandit, B. Lal, and R. K. Rana, Potato Res. 58, $1(2015)$

23. K. P. Prasetyo, M. Harisudin, and E. Widiyanti, E J. AGRISTA 1, 1 (2013)

24. S. Miyata, N. Minot, and D. Hu, World Dev. 37, 1781 (2009)

25. O. E. Ayinde, Agric. J. 3, 447 (2008)

26. X. Yu, Risk Attitudes, Social Interactions and the Adoption of Genotyping in Dairy Production, The University of Guelph, 2014

27. S. Opoku, Biol. Agric. Healthc. 2, 58 (2012)

28. B. P. K. Dewi, B. Setiawan, and R. Isaskar, Habitat 12, 98 (2011)

29. M. Vassalos and Y. Li, Int. Food Agribus. Manag. Rev. 19, 25 (2016)

30. N. Arumugam, F. M. Arshad, E. Chiew, and Z. Mohamed, Int. J. Agric. Manag. Dev. 1, 65 (2011)

31. H. H. Wang, Y. Zhang, and L. Wu, China Agric. Econ. Rev. 3, 489 (2011) 